\title{
Economic Development and Environmental Degradation in Indonesia: Panel Data Analysis
}

\author{
M Irsyad Ilham
}

Abstract: This study analyzed the relationship of economic development, population density, and the number of vehicles on environmental degradation from 31 provinces in Indonesia for the period 2011-2019. Panel data analysis, which is widely used to examine issues that could not be studied in either crosssection or time-series alone, is used herein. The empirical results support the hypothesis on the direction of causality from those three factors of environmental damage in the country. The results concluded that economic development, population density, and the number of vehicles impacted on environmental degradation in Indonesia. The smallest cross-section random effect indicates the lowest environmental quality when all factors are fixed. The empirical findings provide important policy implications for Indonesia and it will direct its economic development model towards a green economic one. On the other hand, the growth of the population should be equalized with growth in human development. The distribution of population should be equalized among provinces by opening a new economic cluster to supply new work-fields. In addition, it should be for the country to create a more-educated population in order to protect environmental quality. Despite the unstoppable growth of vehicles, the government should implement the development of eco-friendly combustion technology besides reducing fuel consumption. Moreover, the roadmaking by plastic-based material can be considered to prevent land damage from plastic waste and might also recycle plastics which has caused pollution in Indonesia.

Keywords: Environmental Quality Index; Economic Development; Population Density; Number of Vehicles; Panel Data Regression

JEL Classification: Q53; Q56; C23

\section{Introduction}

In recent years, one of the most important issues for developing countries is environmental degradation (Kojima, 2007; Todaro \& Smith, 2003; Warren \& McCarthy, 2008). The issue of environmental degradation is still an important research agenda because of its global significance (Rahman, 2017). According to Indonesia's Ministry of Environment and Forest, during 2011-2014, the average environmental quality index posed a low-level and has decreased by $3.56 \%$ in four years. 
Ilham
Economic Development and Environmental Degradation in Indonesia: ...

The data shows the trend of deterioration in water and forest land coverage. The figures captured environmental degradation will bring about several adverse impacts such as endangering ecosystem balance and human health. Hence, this study analyzes the environmental degradation in Indonesia from the viewpoint of the Environmental Quality Index (EQI) by provinces. Due to many factors that have a relationship to environmental quality, this study considered economic development, population density, and the number of motor vehicles as independent variables.

Economic development is also known as a factor that declines environmental quality. The economic development activities often exclude the residues that can pollute the environment. On the other hand, Indonesia's development is also still dependent on natural resources. According to Statistics Indonesia, In 2018 the industrial sector contributed 19.86 percent to the national economy. The agricultural sector contributed 12.81 percent, and 8.08 percent mining. The three sectors used natural resources as raw materials for their production. Degradation of these natural resources occured due to resource depletion and pollution. Furthermore, this study uses the variable of Gross Domestic Regional Product (GRDP) per capita as economic development by the province to analyze its relationship on environmental quality in Indonesia.

The linkages between population and environmental degradation have received increasing attention. The population growth will affect the high pressure on environmental carrying capacity. Todaro and Smith (2003) showed theoretically how population density will relate to environmental degradation. If population density, together with world income levels increase, the net environment will continue to deteriorate in degradation problems. Todaro and Smith (2003) argued that rapid population growth and expanding economic activity in the developing world are likely to do extensive environmental damage unless steps are taken to mitigate their negative consequences. This study also analyzed the relationship of population density with environmental quality. The high population density is considered to have a high demand for natural resources such as water and fossil fuels and adding pressure on environmental capacity.

In the process of development, the increase of population has brought an increasing amount of Indonesian vehicles. The number of vehicles reached an enormous growth in the last few years. Statistics Indonesia showed the total number of vehicles (such as cars, buses, and trucks) in Indonesia increased from over 12 million in 1995 to over 114 million in 2014. The motorcycles (which comprise 81 percent of the total vehicle fleet) alone accounted for more than 700,000 of this increase (from 2011 to 2014). The World Bank accounted for transportation which consumed 12 million kiloliters of gas oil, 12 million kiloliters of premium, 118 thousand kiloliters of diesel oil, 185 thousand kiloliters of fuel oil, and 749 thousand kiloliters of other types of fuel.

While it is becoming increasingly evident that environmental problems such as the growth of total carbon dioxide emission, forest destruction, and water contamination, many governments have engaged in addressing environmental concerns for their development strategies. Therefore, analyzing the causal relationship between environmental 
degradation and several socio-economic determinants has been a popular topic in recent environmental literature (Adams, 2008). Therefore, this study is expected to be a reference and evaluation of environmental issues in Indonesia. This research used panel data to get more information about environmental problems and discuss the factors that influenced environmental degradation. If these factors are proven to be significantly causing environmental degradation, it is necessary to change the pattern of development towards more attention to environmental sustainability.

Overall, this study aims to: (1) describe environmental degradation, economic development, population density, and/or the number of the motor vehicle in Indonesia during 2011-2019, and (2) examine the impact of economic development, population density, and the number of vehicles on environmental degradation in Indonesia during 2011-2019. The current paper differs from the previous study, such as Akbostancl et al. (2009), Arouri et al. (2012), Hung and Shaw (2006), and Ilham (2018). The novelties of this paper are: First, this study employs the Environmental Quality Index which calculates the index as the summation indices of water, Air, and Forest land Coverage. The previous works of literature only used one specific pollutant as a dependent variable for example carbon dioxide emissions and do not include the aggregate value from the other aspect. Second, this study analysed the impact of three independent variables (Gross Domestic Regional Product, population density and number of vehicles) on environmental quality by provincially using a panel data regression model. Finally, this study utilizes the latest data available for 31 provinces and nine years observation period for the estimation process, from 2011 until 2019. The paper is organized as follows. Section II presented the Research Method, Section III showed Results and Discussions, and Section IV provided the Conclusion.

\section{Research Method}

The total number of observations in the study is 279 which consisted of annual data of 31 provinces in Indonesia from 2011 to 2019. The variables in this study include Indonesia's environmental quality index (IEQI), gross domestic regional product per capita (GDRPC), population density (DEN), and the number of vehicles (NV). The data used in this research were secondary. The IEQI was obtained from The Ministry of Environmental and Forest of the Republic of Indonesia, meanwhile, the GRDPC, DEN, and NV are from BPS-Statistics Indonesia. This study also considered adding more control variables particularly those that correlated with environmental quality such as agricultural, Industrial activity, mining sector, and the economic growth from the construction sector.

The environmental quality index is measured by the aggregation of three aspects of environmental quality. Economic development, measured as the gross domestic regional product per capita, uses constant price 2010 in million rupiahs. Population density, calculated by rationing between the number of populations and the size of the area, expressed by people per kilometre square. The number of motor vehicles signed as a unit. The source of data is from Statistics Indonesia and the Ministry of Environment and Forest. The IEQI data indicate that West Papua and the Special Capital Region of Jakarta 
had the highest and lowest average of the environmental quality value of 63,5 and 32,8 , respectively. The Jarque-Bera (J-B) normality test results indicate that IEQI data for 31 provinces are approximately normal.

Meanwhile, the data from Statistics Indonesia shows that the highest and lowest mean of the per capita GDRP is Jakarta (IDR 128,5 million) and East Nusa Tenggara (IDR 10,2 million). The province with the highest population density is Jakarta (14932 people $/ \mathrm{km}^{2}$ ) and the lowest is in West Papua ( 8 people $/ \mathrm{km}^{2}$ ). Thus, the table also shows the highest number of motor vehicle users are from Jakarta province, respectively. The Jarque-Bera (J-B) normality test for those three variables also indicates that economic development, population density, and the number of motor vehicles have an approximately normal distribution.

To obtain the model used in the study, statistical tests and the availability of the data were considered. According to Gujarati and Porter (2008), four considerations can be used to select the model between a fixed effect or random effect model, namely:

1. If the amount of time series ( $\mathrm{T}$ ) data is large and the number of cross-section (N) data is small, the difference between the fixed effect and the random effect model is very small, so the choice is based on the ease of calculation, i.e. the fixed effect model;

2. When the amount of time series $(T)$ data is small and the number of large cross-section (N) data, the estimates obtained by the two methods can differ significantly. In the random effect model, $\alpha_{i}=\alpha+\mu_{i}$ where $\mu_{i}$ is the component of individual error and $\alpha_{i}$ in the fixed effect, the model is not random. If the individual or unit of the crosssection of the sample used is not random, then the fixed effect model is more appropriate to use. Whereas, if the cross-section unit is random, the random effect model is more appropriate to use;

3. If the individual error components $\mu_{i}$ and one or more regressors are correlated, the estimator derived from the random effect model is biased, whereas the fixed effect model is unbiased so that the fixed effect model is better to be used; and

4. If the number of large cross-section $(\mathrm{N})$ data and the number of small-time series $(\mathrm{T})$ data and the assumption of the random effect model are met, the random effect model estimator is more efficient than the fixed-effect model estimator.

The model is as follows,

$$
\ln (E Q I)_{i t}=\alpha_{i}+\beta_{1} \ln (G R D P C)_{i t}+\beta_{2} \ln (D E N)_{i t}+\beta_{3} \ln (N V)_{i t}+\varepsilon_{i t}
$$

The EQI is the Environmental Quality Index, GRDPC is Gross Domestic Regional Product per Capita, DEN is Population Density and NV is Number of Vehicles. The equation is made in the natural logarithm form. Both the left and right side from the equation are made in natural logarithm for several reasons. First, the coefficient can be understood as elasticities. Second, the natural logarithm scale is directly interpretable as an approximate proportional difference or as a percentage point. For instance, if a coefficient $\beta_{1}$ is 0.6 , which means that if the value of gross domestic regional product per capita increases by 1 percent, the environmental quality index will increase by 0.6 percent. 
Building the panel data regression model from econometric criteria, it is needed to test and deal with several problems according to the model assumption. If the selected model is a fixed-effect model or common effect model, the assumption which should be fulfilled is normality, homoscedasticity, non-autocorrelation, and non-multi-collinearity. In special cases, if the selected model is a random effect, the harnessing of Generalized Least Square (GLS) or Feasible GLS to estimate parameters has accommodated the homoscedasticity and non-autocorrelation assumption. Hence, the random effect model uses the assumption of normality and multicollinearity (Heshmati et al., 2015; Singer \& Willett, 2003).

\section{Result and Discussion}

Sustainable development aims to guarantee environmental integrity that comprises the continuity and ecological balance in order not to ruin the cause of economic development. Hence, environmental degradation is an urgent problem faced by the rest of the world, including Indonesia. The environmental quality of Indonesia is one important issue while high pressure has potential adverse effects to the environment as a result of economic growth and population. Therefore, the Ministry of Environment and Forest (2015) had developed a provincial-based index value to explain the environmental condition.

Figure 1 depicted environmental degradation in Indonesia based on the environmental quality index. Those quality's indicators, whether water, air, and even forest coverage index were used to calculate the environmental quality index (EQI). This index can describe the condition of the national environment in aggregate form. The fluctuation of the water quality index during four years may become a warning to be overcome. During 2011-2014, the environmental quality index decreased by $3.56 \%$. The index has increased by $2.67 \%$ during $2015-2019$. Overall environmental quality has an average of 64.67 and is still consistent in moderately good.

The water quality index has an average of 53.19 which is in the bad category. Thus, air quality shows a decreasing trend although the average value can be stated that the air condition is still in good condition. Forest coverage also should be considered to take action, especially by local governments. Besides, the average value of the Forest Coverage index is still picturing low forest management, some illegal logging cases triggered as a factor that causes Indonesia's loss of forest. According to the Ministry of Environment and Forest (2015), the water's quality and forest coverage have decreased significantly because of industrial activities, household pollution, and a new settlement in the riverbank. 
Economic Development and Environmental Degradation in Indonesia: ...

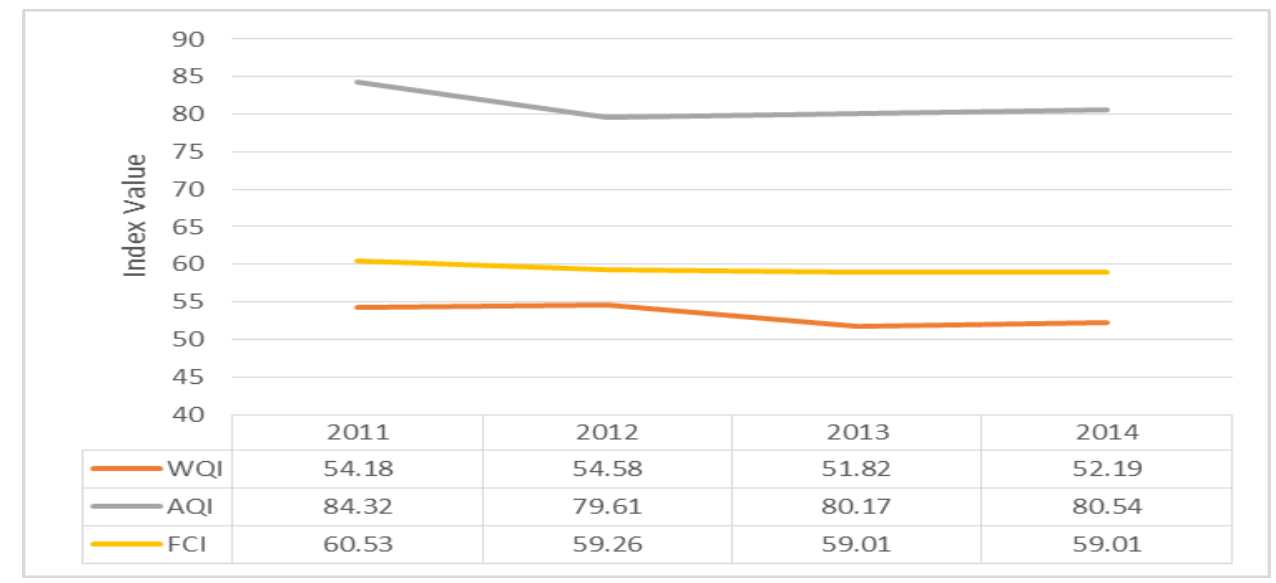

Figure 1 Water Quality Index (WQI), Air Quality Index (AQI), and Forest Coverage Index (FCl)

Source: Ministry of Environment and Forest, 2015

The environmental quality's lowering has been indicated from regional cases. The data shows that West Papua still has the highest environmental quality for four years. On the other hand, Jakarta is still the lowest environmental quality in Indonesia. This special capital region has been the highest environmental problem since 2011. The environmental problem in Jakarta can be known from the three facets, such as water quality, air, and land quality. Tables 1 and 2 showed that from three facets of environmental quality. Jakarta was the lowest quality compared to other provinces.

Table 1 Environmental Quality Index 2011-2014

\begin{tabular}{|c|c|c|c|c|c|}
\hline Province & 2011 & 2012 & 2013 & 2014 & Average \\
\hline \multicolumn{6}{|c|}{ Water Quality Index } \\
\hline Jakarta & $35.65(33)$ & $41.05(33)$ & $34.71(33)$ & $34(33)$ & $36.35(33)$ \\
\hline \multicolumn{6}{|c|}{ Air Quality Index } \\
\hline Jakarta & $47.21(33)$ & $44.31(33)$ & $41.51(33)$ & $46.28(33)$ & $44.83(33)$ \\
\hline \multicolumn{6}{|c|}{ Forest Coverage Index } \\
\hline Jakarta & $32.06(32)$ & $32.06(32)$ & $31.99(32)$ & $31.99(32)$ & $32.03(32)$ \\
\hline
\end{tabular}

The number in parentheses shows ranks of Jakarta from the other provinces in Indonesia Source: Ministry of Environment and Forest, 2015

Furthermore, several provinces have experienced declining environmental status in the danger category such as Jakarta, West Java, and Banten. Supposed that we disaggregated the provinces by three environmental index facets, it can be known that there is a lower status condition that happened by provinces in 2014. In the water quality facet, the provinces of Jakarta, West Java, Central Java, Banten, Yogyakarta, South Kalimantan, and Maluku are classified in the danger category in water quality. In the air quality facet, it is just Jakarta that is classified in the danger category. In the forest quality facet, the average value during 2001-2014 exhibits that the provinces of North Sumatera, Jambi, South Sumatera, Lampung, Bangka Belitung, Jakarta, West Java, Yogyakarta, Banten, Bali, and South Kalimantan are classified in the danger category about losing of its forest coverage (Ministry of Environment and Forest, 2015). Hence, repairing the environment becomes 
needed to achieve the national target of environmental quality. One of the ways is to identify determinants that may cause degradation itself, since socio-economic aspects may be conducted to lead the sustainable development problem.

Table 2 Environmental Quality Index 2015-2019

\begin{tabular}{llllll}
\hline \multicolumn{1}{c}{ Aspect } & 2015 & 2016 & 2017 & 2018 & 2019 \\
\hline Water Quality Index (WQI) & 53.10 & 50.20 & 53.20 & 51.01 & 52.62 \\
Air Quality Index (AQI) & 84.96 & 81.78 & 87.03 & 84.74 & 86.56 \\
Land Forest Coverage Index (FCI) & 58.55 & 58.42 & 60.31 & 61.03 & 62.00 \\
Environmental Quality Index & 64.84 & 62.96 & 66.19 & 65.14 & 66.55 \\
\hline
\end{tabular}

Source: Ministry of Environment and Forest, 2020

The link between development and the environment is subject to an important trade-off. While developing countries aim at achieving a higher standard of living; on the other hand, this development process is based on agricultural and industrial expansion, which is usually resource-consuming and environmentally damaging. Indonesia's economic growth is attributable largely to its rapidly impressive economic activity in the industrial sector. The value of agriculture's economic share of GDP between 2011 and 2014 rose from $13.51 \%$ to $18 \%$. Industrial sector contribution remained greater than agriculture, with growth at a higher rate, rising from $21.76 \%$ to $28.44 \%$ between 2011 and 2014 , and represented as the new national economic backbone. A large portion of industrial economic output was, however, to process the agricultural product. Roughly $68 \%$ of all industrial activity consisted of food crops and plantations in 2014. Taken together, the total value of the agriculture and industrial sector represented over $34 \%$ of the nation's GDP in 2014, up from 32\% in 2011.

Table 3 recorded the share of regional areas for GDP value. It showed that Java still dominated Indonesia's economy by contributing $57,39 \%$ of national GDP, respectively, in 2014. Sumatra comes next, with $23,16 \%$. The highest regional GDP (GRDP) is achieved mostly by provinces with natural resources (oil, gas, and forestry) and business centres like Jakarta, East Kalimantan, Riau Island, and West Papua. While provinces which have less natural resources and business activities are left behind in terms of economic development like Gorontalo, East Nusa Tenggara, Maluku, and West Nusa Tenggara. The highest regional GRP was achieved by Jakarta for 2011 and 2014 at IDR 1,147 trillion and IDR 1,374 trillion. Meanwhile, North Maluku is the lowest regional GRP by IDR 16 trillion in 2011 and IDR 19.2 trillion in 2014. In retrospect, agriculture has been still important to the nation's economy. While Java has been increasing in the importance of the industrial sector, agriculture remains responsible for over $20 \%$ of overall economic activity by the regions (Table 3 ). This could remind us that agriculture and industry still contributed as the regional economic backbone, and also there were consequences for the environmental concern. 
Ilham

Economic Development and Environmental Degradation in Indonesia: ...

Table 3 Distribution of Regional GDP at Current Price by regions and Economic Sectors (\%)

\begin{tabular}{lccccc}
\hline \multirow{2}{*}{ Region } & Year & Agriculture & Industry & Mining & Others \\
\hline Sumatera & 2011 & 22.65 & 19.64 & 19.06 & 38.65 \\
& 2014 & 21.56 & 19.1 & 18.59 & 40.75 \\
Java & 2011 & 8.61 & 29.64 & 2.84 & 58.91 \\
& 2014 & 8.28 & 29.06 & 2.31 & 60.35 \\
Bali-Nusa & 2011 & 21.69 & 29.64 & 2.84 & 45.83 \\
Tenggara & 2014 & 20.37 & 4.77 & 4.02 & 70.84 \\
Kalimantan & 2011 & 11.05 & 17.45 & 42.45 & 29.05 \\
& 2014 & 12.39 & 17.09 & 38.85 & 31.67 \\
Sulawesi & 2011 & 26.78 & 10.54 & 8.64 & 54.04 \\
& 2014 & 26.37 & 10.54 & 8.61 & 54.48 \\
Maluku-Papua & 2011 & 14.28 & 9.71 & 34.11 & 41.9 \\
& 2014 & 15.27 & 9.49 & 24.95 & 50.29 \\
\hline
\end{tabular}

Source: Statistics Indonesia (2016)

Population pressure can be one cause of environmental degradation. The overpopulation will affect human limits of capably producing food and altering the balance of supply and demand. As a result, increasing human demands are damaging natural resources. Discussions of the Indonesian population usually highlight the density contrast between Java and the rest of Indonesia. While Java is densely populated, the rest of Indonesia is sparsely populated. Table 4 shows that the population density increased over time, with the highest density recorded in Java. In 2011, for example, the population density in Java's provinces ranged from 720 persons per square kilometre (in East Java) to 12,685 persons per square kilometre (in Jakarta). In islands other than Java, the uneven distribution of populations also persists. The provinces of Lampung and North Sumatra are the most densely populated regions over time. For both provinces, the population density was more than 100 per square kilometre in 2011 and increased to 162 and 188 in 2014.

It is almost considered a fact that the population in the country will increase in the future. The projections of Indonesia in 2030 is 8.1 billion, nearly $35 \%$ over the present. The fruits of development have created a higher level of income and growing middle and upper classes. As the fruits of economic growth, a higher level of income has meant a higher level of resource consumption and pollution. A vivid example is an increase in the number of motor vehicles in Indonesia, which has resulted in carbon dioxide at rates up to 179,731 kiloTon in 1991 to 599,540 kiloTon in 2012. Ownership rates in Indonesia increased from 85.6 million motors in 2011 to 114.2 million motors in 2014. The total ownership of vehicles in Indonesia is growing at about $10.08 \%$ per year. Table 5 shows the growth of cars, buses, and motorcycles separately since 2011 and shows the total ownership of vehicles in 2014 is growing $33.42 \%$ than in 2011. The rate of growth of the vehicle in the regions is predicted to increase over time and in 2019, the total number of the vehicle reached over 154 million units. 
Table 4 Indonesia's Provincial population density thousand people per square kilometre, 2011-2014

\begin{tabular}{|c|c|c|c|c|c|}
\hline \multirow{2}{*}{ Province } & \multirow{2}{*}{ Area $\left(\mathrm{km}^{2}\right)$} & \multicolumn{4}{|c|}{ Population density (thousand people $/ \mathrm{km}^{2}$ ) } \\
\hline & & 2011 & 2012 & 2013 & 2014 \\
\hline Aceh & 57,956 & 80 & 81 & 83 & 85 \\
\hline North Sumatera & $72,981.23$ & 181 & 184 & 186 & 189 \\
\hline West Sumatera & $42,012.89$ & 117 & 119 & 121 & 122 \\
\hline Riau & $87,023.66$ & 66 & 68 & 69 & 71 \\
\hline Jambi & $50,058.16$ & 63 & 64 & 66 & 67 \\
\hline South Sumatera & $91,592.43$ & 83 & 84 & 85 & 87 \\
\hline Bengkulu & $19,919.33$ & 88 & 90 & 91 & 93 \\
\hline Lampung & $34,623.8$ & 223 & 226 & 229 & 232 \\
\hline Bangka Belitung & $16,424.06$ & 77 & 78 & 80 & 82 \\
\hline Riau Islands & $8,201.72$ & 213 & 220 & 227 & 234 \\
\hline Jakarta & 664.01 & 14687 & 14852 & 15015 & 15173 \\
\hline West Java & $35,377.76$ & 1242 & 1262 & 1282 & 1301 \\
\hline Central Java & $32,800.69$ & 998 & 1006 & 1014 & 1022 \\
\hline Yogyakarta & $3,133.15$ & 1120 & 1134 & 1147 & 1161 \\
\hline East Java & $47,799.75$ & 792 & 797 & 803 & 808 \\
\hline Banten & $9,662.92$ & 1133 & 1159 & 1185 & 1211 \\
\hline Bali & $5,780.06$ & 685 & 693 & 702 & 710 \\
\hline West Nusa Tenggara & $18,572.32$ & 247 & 250 & 254 & 257 \\
\hline East Nusa Tenggara & $48,718.1$ & 98 & 100 & 102 & 103 \\
\hline West Kalimantan & 147,307 & 30 & 31 & 32 & 32 \\
\hline Central Kalimantan & $153,564.5$ & 15 & 15 & 16 & 16 \\
\hline South Kalimantan & $38,744.23$ & 96 & 98 & 99 & 101 \\
\hline East Kalimantan & $129,066.64$ & 18 & 18 & 30 & 26 \\
\hline North Sulawesi & $13,851.64$ & 166 & 168 & 170 & 172 \\
\hline Central Sulawesi & $61,841.29$ & 44 & 44 & 45 & 46 \\
\hline South Sulawesi & $46,717.48$ & 175 & 177 & 179 & 180 \\
\hline South-East Sulawesi & $38,067.7$ & 60 & 62 & 63 & 64 \\
\hline Gorontalo & $11,257.07$ & 94 & 96 & 98 & 99 \\
\hline West Sulawesi & $16,787.18$ & 71 & 72 & 74 & 75 \\
\hline Maluku & $46,914.03$ & 33 & 34 & 35 & 35 \\
\hline North Maluku & $31,982.5$ & 33 & 34 & 35 & 36 \\
\hline West Papua & $97,024.27$ & 8 & 8 & 9 & 9 \\
\hline Papua & $319,036.05$ & 9 & 9 & 10 & 10 \\
\hline
\end{tabular}

Source: Statistics Indonesia (2016)

Table 5 The number of vehicles by types in Indonesia 2011-2014, 2018-2019

\begin{tabular}{lcccccc}
\multicolumn{1}{c}{ Types } & $\mathbf{2 0 1 1}$ & $\mathbf{2 0 1 2}$ & $\mathbf{2 0 1 3}$ & $\mathbf{2 0 1 4}$ & $\mathbf{2 0 1 8}$ & $\mathbf{2 0 1 9}$ \\
\hline Cars & $\mathbf{9 , 5 4 8 , 8 6 6}$ & $10,432,259$ & $11,484,514$ & $12,599,038$ & $16,440,987$ & $17,238,361$ \\
Buses & $\mathbf{2 , 2 5 4 . 4 0 6}$ & $\mathbf{2 , 2 7 3 , 8 2 1}$ & $\mathbf{2 , 2 8 6 , 3 0 9}$ & $\mathbf{2 , 3 9 8 , 8 4 6}$ & $2,538,182$ & $2,541,957$ \\
Freight cars & $\mathbf{4 , 9 5 8 , 7 3 8}$ & $5,286,061$ & $5,615,494$ & $6,235,136$ & $7,778,544$ & $8,007,542$ \\
Motorcycles & $68,839,341$ & $\mathbf{7 6 , 3 8 1 , 1 8 3}$ & $84,732,652$ & $92,976,240$ & $120,101,047$ & $126,588,509$ \\
Total & $85,601,351$ & $94,373,324$ & $104,118,969$ & $114,209,260$ & $146,858,760$ & $154,376,369$ \\
Vehicles & & & & & & \\
\hline
\end{tabular}

Source: Statistics Indonesia (2016) 
Panel data regression analysis was used to predict the impact of economic development, population density, and the number of vehicles on environmental degradation. There are three kinds of panel data such as common effect, fixed effect, and random effect model. Such models have their assumptions. The distinction of assumption is based on its intercept value.

The common effect model (CEM) has an assumption which states that intercepts on the estimation model are the same across all individual terms. In other words, during 20112019 environmental quality index of provinces is the same, ceteris paribus. The second model is the fixed effect model (FEM) that assumes the environmental quality index will differ across provinces which can be identified by its intercept value. The last is the random effect model (REM). Similar to FEM, the random effect model assumes intercept value across provinces is different. However, the intercept in REM shows the deviation between the average value of the intercept and the error' component. In addition, the intercept in REM is assumed as random.

The panel data regression model is used to analyze the effect of economic development, population density, and the number of vehicles on environmental quality is a fixed-effect model as seen in Table 6 and Table 7. The result showed that all independent variables affect the environmental quality index of provinces in Indonesia. The partial test of independent variables shows that the Prob (t-stat) is smaller than 0.05 which concluded that by $5 \%$ significance level, GRDP per capita, population density, and the number of vehicles significantly affected the environmental quality index (EQI).

This study used a fixed effect panel data regression model. The model considered as a fixed effect would produce a more efficient estimate of parameters. If the estimation using common effect would be problematic owing to serial correlation in panel data. Moreover, the common effect model would ignore province-level unobserved heterogeneity which would produce a biased parameter of interest. Meanwhile, the random effect model assumes that the province-specific unobserved is not correlated with the main explanatory variable of interest. The random effect model assumed that the sample is randomly selected from the population. It would be difficult to defend the assumption of correlation between the unobserved heterogeneity and the explanatory variable of interest. Given this consideration, this study uses the fixed effect model.

This paper will estimate the parameters proposed previously by using panel data. As it is known, panel data is the combination between the time series data from 2011-2019 and cross-section data between 31 regions or provinces in Indonesia. By using this combined data, researchers will have rich data as information and the variations which can explain the real condition. In addition, it will obtain better results of regression rather than if we used the time series data or cross-section data only.

The estimation results in Table 6 column 11 showed that gross domestic regional product, population density, and the number of motor vehicles have a negative and significant effect on declining environmental quality. From the variables estimated, it was found that 
the industrial gross domestic regional product was dominant in influencing Indonesia's environmental quality index.

The gross domestic product of industrial has a negative and significant impact on environmental quality in Indonesia, an increase of $1 \%$ on the industrial gross domestic regional product will lead to a decline in environmental quality for $0.201 \%$ cateris paribus. Thus, an increase in per capita gross domestic regional product, population density and the number of motor vehicles for $1 \%$ respectively would decline the environmental quality by about $0.047 \%, 0.081 \%$ and $0.001 \%$ cateris paribus. This result is in line with Hung and Shaw (2006) by using the Kuznet hypothesis through Environmental Kuznets Curve (EKC) and several degradation proxies such as $\mathrm{CO}, \mathrm{SO} 2$, etc, the GDP per capita affected environmental degradation in a country.

The result is also in line with Pandit and Paudel (2016) which concluded income per capita had a positive significant effect on environmental degradation. From their research, environmental degradation was monitored from the amount of phosphorus, BOD contaminants, and even the mercury in the waters. The GRDP per capita showed the level of the community welfare that has occurred in various regions. The GRDP per capita represents a person's income level in an area. The higher one's income, the higher one's ability to gain access to goods and services. The high effort to reach access for the goods or services showed the high demand (demand) for goods or services. In the end, producers are encouraged to produce goods or services to fulfil the supply of goods or services. The interaction between demand and supply of the goods or services, aggregative, will spur economic development. The increase in the quality of human life is accompanied by an increase in the level of resource consumption and pollution.

From the estimation result, to improve the quality of the environment and to reduce the case of environmental degradation, economic development activities in Indonesia must be reduced. However, economic development activities carried out in a country are precisely the main activities carried out in all developing economies to improve the welfare of its people. The impact of economic activity becomes the "cake of development" that should be divided among each community. However, economic development activities, which use a lot of natural resources or environmental inputs should be carried out together with environmental quality.

The population density was the factor that influenced environmental degradation. A large population with relatively high population growth will cause an increase in the need for natural resources as inputs for goods and services. The high demand for natural resources can lead to excessive utilization of natural resources, causing depletion of natural resources. Population density has a significant effect on environmental quality. The result is quite consistent with the findings of Alam (2010). He also found the increase in population density affected the decrease of water quality in Pakistan. From the estimation results, it seemed that to achieve a higher quality of the environment, population density must be reduced. The population is an important capital in carrying out economic activities. Each one percent increase in population on this earth due to birth is important for human survival itself. In response to this, policies relating to population 
density factors in an area should be considered about the negative impact on the environment.

One solution was equalizing the distribution of population. Equitable distribution of population can reduce population density. During this time, population density in an area or province shows the size of the maximum number of people who can inhabit the area. The second solution was educating the population. Education for people was needed to provide information for the residents about protecting the environment. Environmental education also must be easily accessible to be reached by the community.

Another factor that causes environmental degradation is the number of vehicles. The estimation results for the variable of the number of vehicles indicated there was a positive impact on environmental degradation. The number of vehicles harms environmental quality because it exhausts the emissions that pollute the environment. The environment becomes polluted because of the many pollutants in the air. Meanwhile, the vehicles need the fuel to support the combustion process in the engine vehicle to produce the thrust. The combustion process can occur imperfectly so it could produce residuals that polluting the air. The problem of vehicles is not only the impact on reducing air quality but also the use of energy and the use of environmental technology for the vehicle to minimize environmental degradation.

However, from the estimation results, which show the negative impact of motor vehicles on the increasing degradation of Indonesia's environment, it should be understood that the number of motor vehicles must not be reduced to reach a more quality environment. Borhan et al. (2012) mentioned several developing countries are particularly concerned about how to boost economic development as the environment was degraded. In essence, motor vehicles are needed to boost the economic sector, including for the transportation sector, which means taking part in the national economy. Indonesia still needs increased activity in the transportation sector in achieving economic development to increase national welfare. 
Ilham

Economic Development and Environmental Degradation in Indonesia: ...

\section{Appendix}

Table 6 Estimation Result of Fixed Effect Model for the series 2011-2014

\begin{tabular}{|c|c|c|c|c|c|c|c|c|c|c|c|c|}
\hline & \multicolumn{12}{|c|}{ Dependent variable: } \\
\hline & \multicolumn{12}{|c|}{$\log (E Q I)$} \\
\hline & (1) & (2) & (3) & (4) & (5) & (6) & (7) & (8) & (9) & (10) & (11) & (12) \\
\hline \multirow[t]{2}{*}{$\log (G R D P C)$} & $-0.133^{* * *}$ & & & & & & & & & & -0.047 & \\
\hline & $(0.028)$ & & & & & & & & & & $(0.050)$ & \\
\hline \multirow[t]{2}{*}{$\log (A G R)$} & & $-0.191^{* * *}$ & & & & & & -0.006 & -0.005 & 0.139 & & 0.136 \\
\hline & & $(0.052)$ & & & & & & $(0.092)$ & (0.093) & $(0.114)$ & & (0.119) \\
\hline \multirow[t]{2}{*}{$\log ($ IND) } & & & $-0.201^{* * *}$ & & & & & $-0.197^{* *}$ & $-0.197^{* *}$ & -0.096 & & -0.047 \\
\hline & & & $(0.045)$ & & & & & $(0.082)$ & $(0.086)$ & $(0.097)$ & & (0.099) \\
\hline \multirow[t]{2}{*}{$\log ($ MINING) } & & & & $-0.093^{* *}$ & & & & & -0.001 & -0.0003 & & -0.019 \\
\hline & & & & $(0.041)$ & & & & & $(0.046)$ & $(0.045)$ & & $(0.046)$ \\
\hline \multirow[t]{2}{*}{$\log (\mathrm{CONS})$} & & & & & $-0.149^{* * *}$ & & & & & $-0.168^{* *}$ & & -0.103 \\
\hline & & & & & $(0.031)$ & & & & & $(0.080)$ & & $(0.088)$ \\
\hline \multirow[t]{2}{*}{$\log (N V)$} & & & & & & $-0.112^{* * *}$ & & & & & $-0.081^{* *}$ & $-0.077^{*}$ \\
\hline & & & & & & $(0.021)$ & & & & & (0.039) & $(0.040)$ \\
\hline \multirow[t]{2}{*}{$\log (D E N)$} & & & & & & & $-0.165^{* *}$ & & & & -0.001 & 0.009 \\
\hline & & & & & & & $(0.070)$ & & & & $(0.073)$ & $(0.077)$ \\
\hline Obsservation & 124 & 124 & 124 & 124 & 124 & 124 & 124 & 124 & 124 & 124 & 124 & 124 \\
\hline$R^{2}$ & 0.198 & 0.129 & 0.181 & 0.053 & 0.202 & 0.228 & 0.057 & 0.181 & 0.181 & 0.220 & 0.236 & 0.255 \\
\hline Adjusted $\mathrm{R}^{2}$ & -0.072 & -0.164 & -0.095 & -0.267 & -0.067 & -0.032 & -0.261 & -0.107 & -0.119 & -0.078 & -0.044 & -0.053 \\
\hline F Statistic & $\begin{array}{c}22.703^{* * *} \\
(\mathrm{df}=1 \\
92)\end{array}$ & $\begin{array}{c}13.643^{* * *} \\
(\mathrm{df}=1 \\
92)\end{array}$ & $\begin{array}{c}20.342^{* * *} \\
(\mathrm{df}=1 \\
92)\end{array}$ & $\begin{array}{l}5.113^{* *}(\mathrm{df} \\
\quad=1 ; 92)\end{array}$ & $\begin{array}{c}23.310^{* * *} \\
(\mathrm{df}=1 \\
92)\end{array}$ & $\begin{array}{c}27.220^{* * *} \\
(\mathrm{df}=1 \\
92)\end{array}$ & $\begin{array}{c}5.532^{* *} \\
(\mathrm{df}=1 \\
92)\end{array}$ & $\begin{array}{c}10.063^{* * *} \\
(\mathrm{df}=2 \\
91)\end{array}$ & $\begin{array}{c}6.635^{* * *} \\
(\mathrm{df}=3 \\
90)\end{array}$ & $\begin{array}{c}6.262^{* * *} \\
(\mathrm{df}=4 \\
89)\end{array}$ & $\begin{array}{c}9.278^{* * *} \\
(\mathrm{df}=3 \\
90)\end{array}$ & $\begin{array}{l}4.962^{* * *}(\mathrm{df} \\
\quad=6 ; 87)\end{array}$ \\
\hline Note: & ${ }^{*} \mathrm{p}<0.1 ;{ }^{* *} \mathrm{p}$ & $0.05 ;{ }^{* * *} p<c$ & & & & & & & & & & \\
\hline
\end{tabular}


Ilham

Economic Development and Environmental Degradation in Indonesia: ...

Table 7 Estimation Result of Fixed Effect Model for the series 2015-2019

\begin{tabular}{|c|c|c|c|c|c|c|c|c|c|c|c|c|}
\hline & \multicolumn{12}{|c|}{ Dependent variable: } \\
\hline & \multicolumn{12}{|c|}{$\operatorname{Ln}(E Q I)$} \\
\hline & (1) & (2) & (3) & (4) & (5) & (6) & (7) & (8) & (9) & (10) & (11) & (12) \\
\hline \multirow[t]{2}{*}{$\operatorname{Ln}(G R D P C)$} & $0.547^{* * *}$ & & & -0.084 & -0.214 & & -0.284 & 0.027 & & & -0.026 & -0.105 \\
\hline & $(0.140)$ & & & $(0.205)$ & $(0.209)$ & & $(0.216)$ & $(0.046)$ & & & $(0.062)$ & $(0.082)$ \\
\hline \multirow[t]{2}{*}{$\operatorname{Ln}(D E N)$} & & $1.924^{* * *}$ & & $2.086^{* * *}$ & & 0.623 & 0.865 & & 0.121 & & 0.156 & 0.051 \\
\hline & & $(0.333)$ & & $(0.519)$ & & $(0.678)$ & $(0.701)$ & & $(0.092)$ & & $(0.125)$ & (0.143) \\
\hline \multirow[t]{2}{*}{$\operatorname{Ln}(N V)$} & & & $0.405^{* * *}$ & & $0.490^{* * *}$ & $0.297^{* *}$ & $0.367^{* *}$ & & & 0.035 & & 0.068 \\
\hline & & & $(0.065)$ & & $(0.105)$ & $(0.135)$ & $(0.145)$ & & & $(0.022)$ & & (0.046) \\
\hline Observations & 155 & 155 & 155 & 155 & 155 & 155 & 155 & 279 & 279 & 279 & 279 & 279 \\
\hline $\mathrm{R}^{2}$ & 0.110 & 0.213 & 0.238 & 0.214 & 0.244 & 0.243 & 0.254 & 0.001 & 0.007 & 0.010 & 0.008 & 0.016 \\
\hline Adjusted $\mathrm{R}^{2}$ & -0.114 & 0.015 & 0.045 & 0.008 & 0.046 & 0.044 & 0.050 & -0.124 & -0.118 & -0.115 & -0.121 & -0.116 \\
\hline F Statistic & $\begin{array}{c}15.198^{* * *} \\
(\mathrm{df}=1 \\
123)\end{array}$ & $\begin{array}{c}33.293^{* * *} \\
(\mathrm{df}=1 \\
123)\end{array}$ & $\begin{array}{c}38.332^{* * *} \\
(\mathrm{df}=1 \\
123)\end{array}$ & $\begin{array}{c}16.617^{* * *} \\
(\mathrm{df}=2 \\
122)\end{array}$ & $\begin{array}{c}19.702^{* * *} \\
(\mathrm{df}=2 \\
122)\end{array}$ & $\begin{array}{c}19.564^{* * *} \\
(\mathrm{df}=2 \\
122)\end{array}$ & $\begin{array}{c}13.699^{* * *} \\
(\mathrm{df}=3 \\
121)\end{array}$ & $\begin{array}{c}0.333 \\
(\mathrm{df}=1 \\
247)\end{array}$ & $\begin{array}{c}1.733 \\
(\mathrm{df}=1 \\
247)\end{array}$ & $\begin{array}{c}2.401 \\
\text { (df = 1; } \\
247)\end{array}$ & $\begin{array}{c}0.950 \\
(\mathrm{df}=2 \\
246)\end{array}$ & $\begin{array}{c}1.359 \\
(d f=3 \\
245)\end{array}$ \\
\hline Note: & ${ }^{*} p<0.1 ;{ }^{* *} p$ & $05 ;{ }^{* * *} \mathrm{p}<0$ & & & & & & & & & & \\
\hline
\end{tabular}


Ilham

Economic Development and Environmental Degradation in Indonesia: ...

\section{Conclusion}

During 2011-2014, the environmental quality index decreased by $3.56 \%$. The index has increased by $2.67 \%$ during $2015-2019$. Overall environmental quality has an average of 64.67 and is still consistent in low-level quality. The special capital city of Jakarta was the worst quality of the environment, instead of West Java and Banten. Disaggregation of the index shows a decreasing trend of water and forest quality. It was caused by contamination of pollutants in several rivers and forest losses in four years. Panel data regression has been conducted to test the impact of economic development, population density and number of vehicles on the environment. Thus, it concluded that economic development, population density, and the number of vehicles have triggered environmental degradation in Indonesia. Hence, Indonesia has to direct its economic development model, such as a green economy. Since the magnitude showed a negative effect on environmental quality, however, we cannot blame economic activities as a cause of environmental degradation. The key is to formulate the right and consistent policy framework. Besides, it is necessary to conduct intensive coordination with stakeholders, government institutions, and business actors. On the other hand, the growth of the population should be equalized with growth in human development. In addition, the distribution of population should be equalized among provinces which can be supported by opening a new economic cluster to supply a new work-field. Moreover, education is still the most important thing. Education for the population was needed to provide information on protecting environmental quality. Environmental-based education should be accessible to the public. One of which could be implemented by putting environmental-based education in Indonesia's education curriculum. Thus, the unstoppable growth of vehicles should implement the development of eco-friendly combustion technology besides reducing fuel consumption. Road-making by plasticbased material can be considered to prevent land damage from plastic waste. The solutions given here can be considered to protect environmental quality from declining on the recent day, which has been triggered by the progress of development.

\section{References}

Akbostanc1, E., Türüt-Aşık, S., \& Tunç, G. İ. (2009). The relationship between income and environment in Turkey: Is there an environmental Kuznets curve? Energy Policy, 37(3), 861-867. https://doi.org/10.1016/i.enpol.2008.09.088

Alam, S. (2010). Globalization, poverty and environmental degradation: sustainable development in Pakistan. Journal of Sustainable Development, 3(3). https://doi.org/10.5539/isd.v3n3p103

Arouri, M. E. H., Ben Youssef, A., M'henni, H., \& Rault, C. (2012). Energy consumption, economic growth and $\mathrm{CO} 2$ emissions in Middle East and North African countries. Energy Policy, 45, 342-349. https://doi.org/10.1016/i.enpol.2012.02.042

Borhan, H., Ahmed, E. M., \& Hitam, M. (2012). The Impact of Co2 on Economic Growth in Asean 8. Procedia-Social and Behavioral Sciences, 35, 389-397. https://doi.org/10.1016/j.sbspro.2012.02.103

Gujarati, D. N., \& Porter, D. C. (2008). Basic econometrics (5 th Ed). New York: McGraw-Hill Education. 
Heshmati, A., Abolhosseini, S., \& Altmann, J. (2015). The development of renewable energy sources and its significance for the environment. Singapore: Springer.

Hung, M.F., \& Shaw, D. (2006). Economic Growth and the Environmental Kurnets Curve in Taiwan: A Simultaneity Model Analysis. In Boldrin, M., (eds). Long-Run Growth and Economic Development: From Theory to Empirics. United Kingdom: Edward Elgar.

Ilham, M. I. (2018). Economic development and environmental degradation in ASEAN. Signifikan: Jurnal Ilmu Ekonomi, 7(1), 103-112. https://doi.org/10.15408/sjie.v7i1.6024

Kojima, S. (2007). Sustainable development in water-stressed developing countries: a quantitative policy analysis. United Kingdom: Edward Elgar Publishing.

Ministry of Environment and Forest. (2015). Publication of Environmental Quality Index (IKLH) and Publication of Indonesian Environmental Status Book (SLHI). Retrieved from https://www.menlhk.go.id/site/single post/70

Ministry of Environment and Forest. (2020). Publication of Environmental Quality Index (IKLH) and Publication of Indonesian Environmental Status Book (SLHI). Retrieved from https://www.menlhk.go.id//site/download file?file=1609312579.pdf

Pandit, M., \& Paudel, K. P. (2016). Water pollution and income relationships: A seemingly unrelated partially linear analysis. Water Resources Research, 52(10), 7668-7689. https://doi.org/10.1002/2016wr018655

Rahman, M. M. (2017). Do population density, economic growth, energy use and exports adversely affect environmental quality in Asian populous countries? Renewable and Sustainable Energy Reviews, 77, 506-514. https://doi.org/10.1016/j.rser.2017.04.041

Singer, J. D., \& Willett, J. B. (2003). Applied longitudinal data analysis: Modeling change and event occurrence. Oxford University Press.

Todaro, M. P., \& Smith, S. C. (2003). Economic Development. Harlow: Addison-Wesley.

Warren, C., \& McCarthy, J. F. (2008). Community environment and local governance in Indonesia: Locating the commonweal. London: Routledge. 